\title{
Religious Belief, Social Support, and the Acceptance of Intrauterine Device Among Women of Reproductive Age in Klaten, Central Java
}

\author{
Veronica Fenny Wijaya', Setyo Sri Rahardjo²), Rita Benya Adriani3) \\ 1)Masters Program in Public Health, Universitas Sebelas Maret \\ 2)Faculty of Medicine, Universitas Sebelas Maret \\ 3)School of Health Polytechnics, Surakarta
}

\begin{abstract}
Background: Indonesia is one of the developing countries with complex population problems. According to Central Bureau of Statistics, the current population in Indonesia in 2016 reached $258,704,986$ people. One of the government efforts to reduce population growth is the Family Planning (KB) program. This study aimed to determine the socioeconomic determinants, social norm, religion on the use of IUD contraceptive among women in Klaten, Central Java, using Theory of Planned Behavior.

Subjects and Method: This was a cross sectional study conducted in 25 community health centers in Klaten, Central Java, from November to December 2018. A sample of 200 women of reproductive age was collected by simple random sampling. The dependent variable was the use of IUD. The independent variables were education, husband support, health personnel support, employment, income, social norm, religion, intention, attitude, perceived behavior control. The data were measured by questionnaire and analyzed by a multilevel logistic regression.

Result: The use of IUD was positively influenced by higher education $(b=1.40 ; 95 \% \mathrm{CI}=0.12$ to 2.78; $\mathrm{p}=0.047)$, strong husband support $(\mathrm{b}=1.57 ; 95 \% \mathrm{CI}=0.12$ to $3.03 ; \mathrm{p}=0.034)$, strong health personnel support $(b=1.70 ; 95 \% C I=0.14$ to $3.26 ; p=0.033)$, employed $(b=1.50 ; 95 \% C I=0.17$ to 2.99; $\mathrm{p}=0.047)$, high income $(\mathrm{b}=2.14 ; 95 \% \mathrm{CI}=0.36$ to $3.92 ; \mathrm{p}=0.018)$, supportive social norm $(\mathrm{b}=1.50 ; 95 \% \mathrm{CI}=0.49$ to $2.95 ; \mathrm{p}=0.043)$, supportive religion $(\mathrm{b}=1.42 ; 95 \% \mathrm{CI}=0.12$ to $2.84 ; \mathrm{p}=$ o.048), intention $(b=1.75 ; 95 \% \mathrm{CI}=0.15$ to $3.35 ; \mathrm{p}=0.032)$, positive attitude $(b=2.16 ; 95 \% \mathrm{CI}=$ 0.45 to $3.86 ; \mathrm{p}=0.013)$, and perceived behavior control $(\mathrm{b}=1.57 ; 95 \% \mathrm{CI}=0.29$ to $3.11 ; \mathrm{p}=0.046)$. Community health center had a contextual effect on the use of IUD contraception with ICC $=10.6 \%$. Conclusion: The use of IUD is positively influenced by higher education, strong husband support, strong health personnel support, employed, high income, supportive social norm, supportive religion, intention, positive attitude, and perceived behavior control. Community health center has a contextual effect on the use of IUD contraception.
\end{abstract}

Keywords: IUD contraceptive, utilization, community health center, multilevel analysis

\section{Correspondence:}

Veronica Fenny Wijaya. Masters Program in Public Health, Universitas Sebelas Maret, Jl. Ir. Sutami 36A, Surakarta 57126, Central Java, Indonesia. Email: veronicafennyo4@gmail.com.

\section{BACKGROUND}

Indonesia is one of the developing countries with complex problems, one of them is related to the population. According to calculations carried out by the Central Bureau of Statistics and Information of the Ministry of Health in 2016, the current population in Indonesia in 2016 has reached 258,704,986 people. According to the Indonesian Health Profile in 2016, Indonesia's population growth rate in 2016 was $3.24 \%$, the highest population growth rate occurred in 2014, which was 3.70\%.

According to the Directorate of Information Technology and Documentation of the National Population and Family 
Planning Board (2011), the term BKKBN which originally had an extension of the National Family Planning Coordinating Board will change to the National Population Agency and National Family Planning, namely the Agency that has the duty and authority in controlling population, increasing the quality and mobility of the population.

Law of the Republic of Indonesia Number 36 of 2009 concerning Health Article 78 states that health services in family planning $(\mathrm{KB})$ are intended to regulate pregnancy for couples of childbearing age to form healthy and smart future generation and responsible government and guarantee the availability of personnel, service facilities, tools and medicines in providing family planning services that are safe, quality, and affordable by the community.

According to the Indonesian Health Profile in 2016, contraception that is widely used in Indonesia is the injection method (51.53\%), pill (23.17\%), implant (11.37\%), IUD (7.23\%), condom (4.78\%), female surgery contraceptive (1.73\%), male surgery contraceptive (0.18\%). Based on the data and information of the Central Java Provincial Health Office in 2016, the contraception that was widely used in the Central Java Province was the injection (54.2\%),pill (13.2\%), IUD (9\%), female surgery contraceptive (5.6\%), condom (4.5\%), implant (1.3\%), and male surgery contraceptive (0.9\%). Based on the background above, this study aims to determine the socioeconomic determinants, social norms, religion on the use of IUD contraception among women of reproductive age.

\section{SUBJECTS AND METHOD}

\section{Study Design}

This study was an observational analytic study with a cross sectional design. The study was conducted in Klaten District, Central Java, Indonesia, from November to December 2018.

\section{Population and Samples}

The source population used in this study was reproductive age women in Klaten District. A sample of 200 women of reproductive age from 25 community health centers was selected by simple random sampling.

\section{Study Variables}

The dependent variable was the use of IUD contraception. The independent variables were education, employment, husband support, health personnel support, income, social norm, religion, intention, attitude, and perceived behavior control.

\section{Operational Definition of Variables} Education was defined as the highest formal education attained by mother.

Husband support was defined as the support given by the husband to support the mother in using IUD Contraception.

Health personnel support was defined as support provided by health workers (midwive, doctor, or cadre) to support mothers in using IUD Contraception.

Employment was defined as the work of the mother in everyday life.

Income was defined as income over the past 6 months as a result of economic processes or cumulative economic resources from the nuclear family (husband, wife, and children).

Social norm was defined as social norms that apply in the mother's environment regarding the use of IUD contraception.

Religion was defined as a religious belief that applies in the mother's environment regarding the use of IUD contraception.

Intention was defined as the sincerity of mothers to use IUD contraception. 
Attitude was defined as the attitude of mothers towards the use of IUD contraception.

Perceived behavior control was defined as maternal beliefs about the availability of certain resources related to IUD contraceptive use.

Community health center was defined as the center of community activities in the efforts of health services and family planning. Use of IUD contraception was defined as maternal status on the use of IUD contraception.

\section{Study Instrument}

The data were collected by medical record and questionnaire.

\section{Data Analysis}

Univariate analysis was used to see the frequency distribution and the percentage of the sample characteristics. Bivariate analysis was performed to study the relationship between IUD contraceptive use and independent variables using chisquare. Multivariate analysis using multilevel multiple logistic regression.

\section{Research Ethics}

Research ethics include informed consent, anonymity, confidentiality, and ethical approval. The research ethics was obtained from Faculty of Medicine, Universitas Sebelas Maret, Surakarta, Central Java, with number 370/UN27.6/KEPK / 2018.

\section{RESULTS \\ 1. Sample Characteristics}

Table 1 showed that mothers who did not use an IUD were 60 (30\%), while those who used an IUD were 140 (70\%). Mothers who have low education are 53 (26.5\%), while those who have higher education are 147 (73.5\%).

Mothers who had low husband support for the use of IUDs were 50 (25\%), while those who had high husband support for the use of IUDs were 150 (75\%).
Mothers who had low support from health personnel for the use of IUDs were 51 (25.5\%), while those who had the support of high health personnel for the use of IUDs were 149 (74.5\%).

Mothers who work at home are 61 (30.5\%), while mothers who work outside the home are 139 (69.5\%).

Mothers who have income $<$ minimum wage are $64(32 \%)$, while those who have income $\geq$ minimum wage are $136(68 \%)$.

Mothers who have social norms do not support the use of IUDs as much as 59 (29.5\%), while those who have social norms support the use of IUDs as much as 141 (70.5\%).

Mothers who have a religion do not support the use of IUDs amounting to 64 (32\%), while mothers who have a religion support the use of IUDs of 136 (68\%).

Mothers who have low intentions in using an IUD are 52 (26\%), while mothers who have a high intention to use IUD are 148 (74\%). Mothers who have a negative attitude in using IUD are 51 (25.5\%), while mothers who have a positive attitude in the use of an IUD of 149 (74.5\%).

Mothers who had a perception of low behavioral control over IUD use were 59 (29.5\%), while mothers who had a high perception of behavioral control over IUD use were 141 (70.5\%).

\section{Bivariate Analysis}

Table 2 showed that there was a relationship between education and the use of IUD contraceptive and it was statistically significant. Mothers who have high level of education were 9.50 times more likely to use IUD contraceptivethan low-educated mothers $(\mathrm{OR}=9.50 ; 95 \% \mathrm{CI}=4.65$ to 19.35; $\mathrm{p}<0.001)$.

There was a relationship between husband support and the use of IUD contraceptive and it was statistically significant. Mothers who have strong husbands 
Journal of Maternal and Child Health (2019), 4(3): 201-211

https://doi.org/10.26911/thejmch.2019.04.03.07

support were 10.13 times more likely to use IUD contraceptive than mothers who have weak husband support (OR=10.13; 95\% CI $=4.90$ to $21.01 ; \mathrm{p}<0.001)$,

There was a relationship between health personnel support and the use of IUD contraceptive and it was statistically significant. Mothers with strong health personnel support were 8.30 times more likely to use IUD contraceptive than mothers with weak health personnel support

\section{Table 1. Sample characteristics}

\begin{tabular}{|c|c|c|}
\hline $\begin{array}{r}\text { Subjects Characteristics } \\
\end{array}$ & Total(n) & Percentage(\%) \\
\hline \multicolumn{3}{|l|}{ IUD contraception use } \\
\hline - not use (code o) & 60 & 30 \\
\hline - Using (code 1) & 140 & 70 \\
\hline \multicolumn{3}{|l|}{ Education } \\
\hline - Low< SHS (code o) & 53 & 26.5 \\
\hline - High $\geq$ SHS (code 1$)$ & 147 & 73.5 \\
\hline \multicolumn{3}{|l|}{ Husband Support } \\
\hline - Weak<3.99 (code o) & 50 & 25 \\
\hline - Strong $\geq 3.99(\operatorname{code} 1)$ & 150 & 75 \\
\hline \multicolumn{3}{|l|}{ Health Personnel Support } \\
\hline - Weak $<4.9$ (code 0$)$ & 51 & $25 \cdot 5$ \\
\hline - Strong $\geq 4.9$ (code 1$)$ & 149 & 74.5 \\
\hline \multicolumn{3}{|l|}{ Occupation } \\
\hline - Working at home (code o) & 61 & 30.5 \\
\hline - Working outside of house (code 1 ) & 139 & 69.5 \\
\hline \multicolumn{3}{|l|}{ Income } \\
\hline - Income $<$ Rp 1,616,652 (code o) & 64 & 32 \\
\hline - Income $\geq$ Rp 1,616,652 (code 1$)$ & 136 & 68 \\
\hline \multicolumn{3}{|l|}{ Social Norms } \\
\hline - Not supporting < 3.91 (code o) & 59 & 29.5 \\
\hline - Supporting $\geq 3.91(\operatorname{code} 1)$ & 141 & 70.5 \\
\hline \multicolumn{3}{|l|}{ Religion } \\
\hline - Not supporting $<4.62$ (code 0$)$ & 64 & 32 \\
\hline - Supporting $\geq 4.62(\operatorname{code} 1)$ & 136 & 68 \\
\hline \multicolumn{3}{|l|}{ Intention } \\
\hline - Negative $<6.99$ & 52 & 26 \\
\hline - Positive $\geq 6.99$ & 148 & 74 \\
\hline \multicolumn{3}{|l|}{ Behavior } \\
\hline - Negative $<6.95$ & 51 & $25 \cdot 5$ \\
\hline - Positive $\geq 6.95$ & 149 & 74.5 \\
\hline \multicolumn{3}{|l|}{ The perception of behavior control } \\
\hline - Weak $<6.96$ & 59 & 29.5 \\
\hline - Strong $\geq 6.96$ & 141 & 70.5 \\
\hline
\end{tabular}

$(\mathrm{OR}=8.30 ; 95 \% \mathrm{CI}=4.07$ to $16.84 ; \mathrm{p}$ $<0.001)$

There was a relationship between employment and the use of IUD contraceptive and it was statistically significant. Mothers who worked outside the house were 17.14 times more likely to use IUD contraceptive than mothers who worked as housewives $(\mathrm{OR}=17.14 ; 95 \% \mathrm{CI}=8.11$ to $36.24 ; \mathrm{p}<0.001)$ 
Wijaya et al./ Religious Belief, Social Support, and the Acceptance

Table 2. Bivariate analysis using Chi-Square Test

\begin{tabular}{|c|c|c|c|c|c|c|c|c|c|}
\hline \multirow[b]{2}{*}{ Variable } & \multirow[b]{2}{*}{ Category } & \multicolumn{4}{|c|}{ The Use of IUD } & \multirow[b]{2}{*}{ OR } & \multicolumn{2}{|c|}{ CI (95\%) } & \multirow[b]{2}{*}{$\mathbf{p}$} \\
\hline & & No & (\%) & Yes & (\%) & & $\begin{array}{l}\text { Lower } \\
\text { Level }\end{array}$ & $\begin{array}{l}\text { Upper } \\
\text { Level }\end{array}$ & \\
\hline \multirow[t]{2}{*}{ Education } & Low & 35 & 58.3 & 18 & 12.9 & \multirow[t]{2}{*}{9.50} & \multirow[t]{2}{*}{4.65} & \multirow[t]{2}{*}{19.35} & \multirow[t]{2}{*}{$<0.001$} \\
\hline & High & 25 & 41.7 & 122 & 87.1 & & & & \\
\hline \multirow{2}{*}{$\begin{array}{l}\text { Husband } \\
\text { support }\end{array}$} & Weak & 34 & 56.7 & 16 & 11.4 & \multirow[t]{2}{*}{10.13} & \multirow[t]{2}{*}{4.90} & \multirow[t]{2}{*}{21.01} & \multirow[t]{2}{*}{$<0.001$} \\
\hline & Strong & 26 & $43 \cdot 3$ & 124 & 88.6 & & & & \\
\hline Health & Weak & 33 & 55 & 18 & 12.9 & \multirow[t]{2}{*}{8.30} & \multirow[t]{2}{*}{4.10} & \multirow[t]{2}{*}{16.84} & \multirow[t]{2}{*}{$<0.001$} \\
\hline $\begin{array}{l}\text { Personnel } \\
\text { Support }\end{array}$ & Strong & 27 & 45 & 122 & 87.1 & & & & \\
\hline \multirow[t]{2}{*}{ Occupation } & $\begin{array}{l}\text { Working at } \\
\text { home }\end{array}$ & 43 & 71.7 & 18 & 12.9 & \multirow[t]{2}{*}{17.14} & \multirow[t]{2}{*}{8.11} & \multirow[t]{2}{*}{36.24} & \multirow[t]{2}{*}{$<0.001$} \\
\hline & $\begin{array}{l}\text { Working } \\
\text { outside home }\end{array}$ & 17 & 28.3 & 122 & 87.1 & & & & \\
\hline \multirow[t]{2}{*}{ Income } & $\begin{array}{l}<\text { minimum } \\
\text { wage }\end{array}$ & 34 & 56.7 & 30 & 21.4 & \multirow[t]{2}{*}{4.80} & \multirow[t]{2}{*}{2.50} & \multirow[t]{2}{*}{9.20} & \multirow[t]{2}{*}{$<0,001$} \\
\hline & $\begin{array}{l}\geq \text { minimum } \\
\text { wage }\end{array}$ & 26 & $43 \cdot 3$ & 110 & 78.6 & & & & \\
\hline \multirow[t]{2}{*}{ Social Norm } & $\begin{array}{l}\text { Not } \\
\text { supporting }\end{array}$ & 34 & 56.7 & 25 & 17.9 & \multirow[t]{2}{*}{6.01} & \multirow[t]{2}{*}{3.10} & \multirow[t]{2}{*}{11.75} & $<0.001$ \\
\hline & Supporting & 26 & $43 \cdot 3$ & 115 & 82.1 & & & & \\
\hline Religion & $\begin{array}{l}\text { Not } \\
\text { supporting }\end{array}$ & 41 & 68.3 & 23 & 16.4 & $\begin{array}{c}10.9 \\
8\end{array}$ & 5.42 & 22.20 & $<0,001$ \\
\hline & Supporting & 19 & 31.7 & 117 & 83.6 & & & & \\
\hline Intention & Negative & 31 & 51.7 & 21 & 15 & 6.06 & 3.05 & 12.04 & $<0,001$ \\
\hline & Positive & 29 & 48.3 & 119 & 85 & & & & \\
\hline Behavior & Negative & 31 & 51.7 & 20 & 14.3 & 6.41 & 3.21 & 12.83 & $<0.001$ \\
\hline Perception of & $\begin{array}{l}\text { Positive } \\
\text { Strong }\end{array}$ & $\begin{array}{l}29 \\
40\end{array}$ & $\begin{array}{l}48.3 \\
66.7\end{array}$ & $\begin{array}{c}120 \\
19\end{array}$ & $\begin{array}{l}85.7 \\
13.6\end{array}$ & 12.74 & 6.20 & 26.23 & $<0.001$ \\
\hline behavior control & Weak & 20 & $33 \cdot 3$ & 121 & 86.4 & & & & \\
\hline
\end{tabular}

There was a relationship between income and the use of IUD contraceptive and it was statistically significant. Mothers who have high income were 4.79 times more likely to use IUD contraceptive than mothers with low income $(\mathrm{OR}=4.79 ; 95 \%$ $\mathrm{CI}=2.50$ to $9.20 ; \mathrm{p}<0.001)$.

There was a relationship between social norm and the use of IUD contraceptive and it was statistically significant. Mothers who have supportive social norm were 6.01 times more likely to use IUD contraceptive than mothers who did not have supportive social norm $(\mathrm{OR}=6.01$; 95\% $\mathrm{CI}=3.10$ to $11.75 ; \mathrm{p}<0.001$ ).

There was a relationship between religion and the use of IUD contraceptive and it was statistically significant. Mothers who have religion that support the use of
IUD contraceptive were 10.98 times more likely to use IUD contraceptive than mothers who have religion that did not allowed the use of IUD contraceptive (OR= 10.98; $95 \% \mathrm{CI}=5.43$ to 22.20 ; $\mathrm{p}<0.001$ ).

There was a relationship between intention and the use of IUD contraceptive and it was statistically significant. Mother with positive intention were 6.06 times more likely to use IUD contraceptive than mother with negative intention $(\mathrm{OR}=6.06$; 95\% $\mathrm{CI}=3.05$ to 12.04 ; $\mathrm{p}<0.001$ ).

There was a relationship between attitude and the use of IUD contraceptive and it was statistically significant. Mother with positive attitude were 6.41 times more likely to use IUD contraceptive than mother with negative attitude $(\mathrm{OR}=6.41 ; 95 \% \mathrm{CI}=$ 3.21 to $12.83 ; \mathrm{p}<0.001$ ) 
There was a relationship between perceived behavioral control and the use of IUD contraceptive and it was statistically significant. Mothers who have strong perceived behavioral control were 12.74 times more likely to use IUD contraceptive than mothers who have weak perceived behavior control $(\mathrm{OR}=12.74 ; 95 \% \mathrm{CI}=6.18$ to 26.23 ; $\mathrm{p}<0.001)$.

\section{Multivariate Analysis}

Table 3 showed that there was a relationship between education and the use of IUD contraceptive. Women with education $\geq$ senior high school had logodd to use IUD by 1.40 units higher than education $<$ senior high school $(b=1.40 ; 95 \% \mathrm{CI}=0.12$ to 2.78; $\mathrm{p}=0.047$ ).

There was a relationship between husband support and the use of IUD contraceptive. Women with strong husband support had logodd to use IUD by 1.6 units higher than women with weak husband

Table 3. The result of multilevel multiple logistic regression

\begin{tabular}{lcccc}
\hline \multirow{2}{*}{ Independent Variables } & \multirow{2}{*}{$\mathbf{b}$} & \multicolumn{2}{c}{ CI (95\%) } & \multirow{2}{*}{ (9) } \\
\cline { 3 - 4 } & & Lower Limit & Upper Limit & \\
\hline Education & 1.40 & 0.02 & 2.78 & 0.047 \\
Husbands Support & 1.60 & 0.12 & 3.03 & 0.034 \\
Health Personnel Support & 1.70 & 0.14 & 3.26 & 0.033 \\
Employment & 1.50 & 0.02 & 2.99 & 0.047 \\
Income & 2.14 & 0.36 & 3.92 & 0.018 \\
Social Norm & 1.50 & 0.05 & 2.95 & 0.043 \\
Religion & 1.42 & 0.01 & 2.84 & 0.048 \\
Intention & 1.75 & 0.15 & 3.35 & 0.032 \\
Attitude & 2.16 & 0.45 & 3.86 & 0.013 \\
Perceived Behavioral Control & 1.57 & 0.03 & 3.11 & 0.046 \\
Community Health Center & 0.39 & 0.002 & 87.50 & \\
N observation=200 & & & & \\
N group=25 & & & & \\
Log likelihood= $=-37.44$ & & & & \\
Prob>Chi2= 0.34 & & & & \\
ICC $=$ 10.6\% & & & & \\
\hline
\end{tabular}

There was a relationship between social norm and the use of IUD contraceptive. Mothers who have supportive social support $(\mathrm{b}=1.57 ; 95 \% \mathrm{CI}=0.12$ to $3.03 ; \mathrm{p}=$ 0.034).

There was a relationship between health personnel support and the use of IUD contraceptive. Women with strong health personnel support had logodd to use IUD by 1.70 units higher than women with weak health personnel support $(b=1.70$; $95 \% \mathrm{CI}=0.14$ to 3.26 ; $\mathrm{p}=0.033$ ).

There was a relationship between employment and the use of IUD contraceptive. Employed mother had logodd to use IUD by 1.50 units higher than women who worked as housewive $(\mathrm{b}=1.50$; $95 \% \mathrm{CI}=$ 0.17-2.99; $p=0.047$ ).

There was a relationship between income and the use of IUD contraceptive. Mothers with high income had logodd to use IUD by 2.14 units higher than women who with low income $(b=2.14 ; 95 \% \mathrm{CI}=$ 0.36 to $3.92 ; p=0.018$ ). 
supportive social norm $(b=1.50 ; 95 \% \mathrm{CI}=$ 0.49-2.95; $\mathrm{p}=0.043$ ).

There was a relationship between religion and the use of IUD contraceptive. Mother with supportive religion had logodd to use IUD by 1.42 units higher than women with non-supportive religion $(\mathrm{b}=$ 1.42; 95\% CI= 0.12-2.84; $\mathrm{p}=0.048$ ).

There was a relationship between intention and the use of IUD contraceptive. Mothers with positive intention had logodd to use IUD by 1.75 units higher than women with negative intention $(b=1.75 ; 95 \% \mathrm{CI}=$ 0.15 to $3.35 ; \mathrm{p}=0.032$ ).

There was a relationship between attitude and the use of IUD contraceptive. Mothers with positive attitude had logodd to use IUD by 2.16 units higher than women with negative attitude $(b=2.16 ; 95 \%$ $\mathrm{CI}=0.45-3.86 ; \mathrm{p}=0.013$ ).

There was a relationship between perceived behavioral control and the use of IUD contraceptive. Mothers with strong perceived behavioral control had logodd to use IUD by 1.57 units higher than women with weak perceived behavior control $(\mathrm{b}=$ 1.57; 95\% CI=0.29-3.11; $\mathrm{p}=0.046$ ).

Community health center had contextual effect on the use of IUD contraception with $\mathrm{ICC}=10.6 \%$.

\section{DISCUSSION}

1. The relationship between education and IUD contraception uptake

The result of this study showed that there was a relationship between education and the use of IUD contraceptivewhich was statistically significant.

The result of this study was in line with a study done by Johana (2013), which stated that there was a relationship between education and the use of long-term contraceptive method ( $\mathrm{OR}=2.8$ ). Mothers who have high level of education were 2.8 times more likely to use LTCM than mothers who have low education. Education was one of the factors that greatly determined someone's knowledge and perception of the importance of things, including the importance of participation in family planning.

The result of this study was in line with a study by Sebastian (2014), which stated thatthere was a relationship between the proportion of FP LTCM use by respondents who were low-educated and highly-educated $(\mathrm{OR}=5.25)$.

Education was very influential in someone's mindset, this was because someone who was highly educated would have a broader view, and accept innovative ideas. The relationship between education, mindset, perception, and behavior was indeed very significantly in society, in the sense that the higher the education, the more rational the decision making.

\section{The relationship between husband support and IUD contraception uptake}

The result of this study showed that there was a relationship between husband support and the use of IUD contraceptive which was statistically significant. The result of this study was in line with a study by Ginting (2017), which stated that there was an effect of husband support on IUD acceptors.

Husbands were influential in giving support to their wives to choose the contraception they want to use for their wives, family planning also mean a plan for planning a married couple to get the desired birth, regulating the birth interval, and determining the number of children according to their abilities and according to community situations and the country, therefore, husband's support for contraception control was needed so that no one was blamed in this matter. The result of this study was in line with Nana (2013), which 
stated that there was a relationship between husband's support and the use of IUD.

\section{The relationship between health personnels support and IUD contraception uptake}

The result of this study showed that there was a relationship between health personnel support and the use of IUD contraceptive which was statistically significant. The result of this study was in line with a study by Ratna (2018), which stated that there was a relationship between health personnel support and the use of IUD.

One of the forms of support from health personnels was the implementation of family planning counseling. Health personnels played a role as counselors to IUD acceptors, namely by providing explanations about various types of contraception including benefits, losses, and side effects of using IUD contraception. The role of health personnel was only providing information rather than determining what contraceptive method that would be used by family planning acceptors.

\section{The relationship between employ- ment and the use of IUD contra- ceptive}

The result of this study showed that there was a relationship between employment and the use of IUD contraceptive which was statistically significant. The result of this study was in line with a study by Elif (2018), which stated that there was a relationship between employment and the use of IUD. A study by BKKBN (2011), stated that employment has a very significant effect on contraceptive use, so it was very likely that working women were more aware of the uses and benefits of IUD than women who did not work.

Employment was one of the influences for someone to choose contraception, employment was an important factor in making a decision to conduct an IUD contraception installation both in terms of the economy or women who wanted to postpone their pregnancy because they want to focus on their job.

\section{The relationship between income and the use of IUD contraceptive}

The result of this study showed that there was a relationship between income and the use of IUD contraceptive which was statistically significant. The result of this study was in line with a study by Carrie (2018), which stated that there was a relationship between income and the use of IUD.

The amount of income was related to purchasing power, individual purchasing power can also affect the use of contraception. Indirectly, purchasing power was also influenced by subsidies from the government, because some regions in Indonesia got subsidies from the government for the installation of IUD. The family economy gave an effect to the people in the village or urban areas, the effect given was not limited to the price of contraceptive services or contraception itself, but included the money that must be spent on contraception services (Soekanto, 2014).

\section{The relationship between social norm and the use of IUD contra- ceptive}

The result of this study showed that there was a relationship between social norm and the use of IUD contraceptive which was statistically significant. The result of this study was in line with a study by Norman et al. (2013), which stated thatthere was a relationship between social culture and the use of IUD.

The result of this study was in line with a study by Laras (2015), which stated thatthere was a relationship between social culture and the use of IUD (OR $=1.55$; $\mathrm{p}=0.004)$. The socio-cultural conditions and environmental conditions influenced the selection of contraceptive methods, this 
was certainly related to the knowledge and understanding of the community about the importance of family planning programs to control pregnancy in order to improve family welfare.

Aritonang (2010) also stated that as social beings, humans cannot be separated from culture and can even be influenced by the culture in which they live. Social norm concerning custom, tradition, habit, rule, and opinion. The use of contraception was also influenced by cultural factors considering that the user lived in a cultural environment. In addition, the use of contraception was related to the habits of people who lived in the environment, someone would be interested in using a contraception if the people around her/him also used the same tools.

\section{The relationship between religion and the use of IUD contraceptive}

The result of this study showed that there was a relationship between religion and the use of IUD contraceptive which was statistically significant. The result of this study was in line with a study by Iswarati (2004), which stated that other challenges in family planning were from various aspects, namely the aspect of service, contraceptive availability, and delivering counseling in terms of cultural barriers which in some areas the community was still familiar with the term "each child brings their own fortune".

The result of this study was in line with a study done by Soemitro (1992), The results of the study showed that the factors that influence the choice of long-term contraception were places to get contraceptive services, the community, religion, employment, and contraceptive services. According to the theory, each religion encouraged its people to have many children, but also must refer to the achievement of children who were qualified.

\section{The relationship between intention and the use of IUD contraceptive}

The result of this study showed that there was a relationship between intention and the use of IUD contraceptive which was statistically significant. The result of this study was in line with a study by Joeliatin (2016), which stated that there was a relationship between intention and the use of IUD.

Intention was someone's tendency to conduct something or not. This strong or weak intention was determined by the extent to which the mother has positive intentions on certain behaviors, and the extent to which she chose to conduct a behavior (Eng and Parker, 2002). Mothers who have the intention and plan to take the IUD Contraception Method have a great chance to realize their intentions in real participation.

\section{The relationship between attitude and the use of IUD contraceptive}

The result of this study showed that there was a relationship between attitude and the use of IUD contraceptive which was statistically significant.

The result of this study was in line with a study by Handayani (2010), which stated that there was a relationship between attitude and the use of IUD (OR=3.0). Mothers who have positive attitude toward long-term contraceptive method were 3 times more likely to bethe participants of long-term contraceptive method than women of reproductive age who have negative attitude.

The result of this study was in line with a study by Ari (2015), which stated that there was a relationship between attitude and the use of IUD. Attitude and belief showed a person's potential or were familiar with the term self-determination. A strong individual, able to react authenti- 
cally and purely, and has truth about stability and strength in him/her.

Attitude was determined by the individual's beliefs about the consequences of showing a behavior (behavioral beliefs) based on the results of an evaluation of the consequences (outcome evaluation). These attitudes were believed to have a direct effect on the intention to behave and were associated with subjective norms and perceived behavioral control (Washington, 2015). The more positive the maternal attitude, the greater the likelihood of using IUD Contraception.

\section{The relationship between per- ceived behavioral control and the use of IUD contraceptive}

The result of this study showed that there was a relationship between perceived behavioral control and the use of IUD contraceptive which was statistically significant. The result of this study was in line with a study by Trisna (2014), which stated that there was a relationship between maternal knowledge and perception with the use of IUD.

The result of this study showed that there was adirect and significant relationship between perceived behavioral control and women of reproductive age's intention to be the participants of long-term contraceptive method. This mean that the better the perceived behavioral control of women of reproductive age, the stronger the intention to become participants in the long-term contraceptive method.

\section{The relationship between com- munity health center and the use of IUD contraceptive}

The results of multilevel analysis was ICC = 10.6\%. The indicator showed that the condition of the health center in each strata has a contextual influence on the variation of IUD contraceptive use by $10.6 \%$. In this study, data was obtained that the strata of the health centers included health centers that were not accredited, basic accredited, and madya accredited. Community health centers with madya level increased the likelihood of using IUD Contraception rather than basic and not accredited health center.

\section{REFERENCES}

Aritonang J (2010). Hubungan budaya patriarki terhadap keputusan WUS menjadi akseptor keluarga berencana di Lingkungan VI Simpang Selayang Medan Tuntungan Tahun 2010, Universitas Sumatera Utara.

BKKBN (2011). Analisis Lanjut 2011, faktor-faktor yang mempengaruhi penggunaan MKJP di enam wilayah Indonesia. BKKBN.

Carrie C, Sarah C (2018). Postpartum intrauterine device placement a patient friendly option. Contraception and Reproductive Medicine. 3:3.

Desy H (2010). Faktor-faktor yang mempengaruhi ibu dalam pengambilan keputusan memilih alat kontrasepsi dalam rahim (AKDR) di wilayah bidan praktik swasta Sri Suparti Boyolali. Jurnal KesMaDaSka, 1(1): 56-65.

Elif O, Ezel B, Duygu K, Sinan Y, Zahide K, Aysun A. Use of Family Methods and Influecing Factors Among Women in Erzurum. Medical Science Monitor, 24: 5027-5034.

Ginting $T$ (2017). Pengaruh dukungan suami terhadap akseptor KB IUD di Desa Klumpang Kampung Kecamatan Hamparan Perak Kabupaten Deli Serdang Tahun 2017. Jurnal Ilmiah Simantek. 1(3).

Haryati T (2014). Pengaruh pengetahuan dan persepsi ibu terhadap pemakaian alat kontrasepsi dalam rahim (AKDR) 
di Kelurahan Sei Sikambing B Medan. Jurnal Keperawatan Flora. 7(2).

Joeliatin, Murti B, Suryani N (2016). Theory of planned behavior on the determinan of participation in the longterm contraceptive method among woman of reproductive age, in Nganjuk, East Java. Journal of Health Promotion and Behavior, 1(3): 171-179.

Johana DB, Agnes M, Gresty M (2013). Faktor-faktor yang berhubungan dengan pemilihan alat kontrasepsi dalam rahim (AKDR) bagi akseptor KB di Puskesmas Jailolo. Jurnal eNers (eNS), 1(1): 1-10.

Kementerian Kesehatan Indonesia. Profil Kesehatan Indonesia Tahun 2016. http://depkes.go.id

Nana A (2013). Faktor-faktor yang berhubungan dengan penggunaan alat kontrasepsi dalam rahim (AKDR) di wilayah kerja Puskesmas Kabun Kabupaten Rokan Hulu Tahun 2013. Jurnal Maternity and Neonatal. 1(3).

Norman DG, Petrus SS (2013). Intrauterine contraception after cesarean section and during lactation: a systematic review. International Journal of Women's Health.

Ratna B (2018). Faktor-faktor yang berhubungan dengan penggunaan kontrasepsi IUD pada wanita usia subur di Desa Tanjungtani Kecamatan Prambon Kabupaten Nganjuk Tahun 2016. Global Health Science, 3(1).

Sebastian E, John K, Cecilia E, Jacob N, Justice N, Moses A, Determinants of Modern Family Planning Use Among of Reproductive Age in the Nkwanta District of Ghana: a case control study. Reproductive Health, 11:65.

Undang-Undang Republik Indonesia Nomor 36 Tahun 2009 tentang Kesehatan.

Washington CI, Jamsidi R, Thung SF, Nayeri UA, Caughey AB, Werner EF (2015). Timing of Postpartum Intrauterine Device Placement: a costeffectiveness analysis, Fertil Steril. 103:131-7. 